\author{
Dr. sc. Damir Primorac* \\ Dr. sc. Maja Buhovac ** \\ Marko Pilić, mag. forens.
}

\title{
EUROPSKI ISTRAŽNI NALOG KAO NOVI INSTRUMENT PRAVOSUDNE SURADNJE DRŽAVA ČLANICA U KAZNENIM PREDMETIMA S POSEBNIM OSVRTOM NA HRVATSKO PRAVO
}

Ulazak u Europsku uniju za Republiku Hrvatsku značio je posve novo razdoblje u njezinu povijesnom i društvenom razvoju. Na području kaznenog prava to je podrazumijevalo implementaciju i harmonizaciju niza instituta kojima je cilj olakšati postupanje pravosudnih tijela i njihovu suradnju u kaznenim predmetima između država članica. U pet godina učinjeni su određeni koraci na tom putu. Međutim, osim analize učinjenog u ovom je razdoblju vrlo važno upozoriti i na otvorena pitanja čija praktična implikacija tek slijedi. Stoga je cilj rada uputiti na institut europskoga istražnog naloga koji je u hrvatsko kazneno zakonodavstvo, u skladu s Direktivom 2014/41/EU Europskog parlamenta i Vijeća od 3. travnja 2014. godine o europskom istražnom nalogu u kaznenim stvarima, uveden Zakonom o izmjenama $i$ dopunama Zakona o pravosudnoj suradnji u kaznenim stvarima s državama članicama Europske unije u listopadu 2017. godine, a novi je institut u pravnim sustavima idrugih država članica. Europski je istražni nalog nakon implementacije europskoga uhidbenog naloga nastavak nastojanja harmonizirana djelovanja pravosudnih tijela država članica Europske unije u kaznenom postupku u cilju pribavljanja dokaza istražnim mjerama. Premda njegove implikacije tek slijede, radom se prikazuju prednosti njegova uvođenja i nedostatci koji proizlaze iz tumačenja pojedinih zakonskih odredaba i stavova kaznenopravne javnosti.

Ključne riječi: europski istražni nalog; pravosudna suradnja; provođenje dokazne radnje; država izdavateljica; država izvršiteljica.

\footnotetext{
Dr. sc. Damir Primorac, izvanredni profesor, Sveučilišni odjel za forenzične znanosti Sveučilišta u Splitu; Pravni fakultet Sveučilišta u Mostaru i odvjetnik (Associate Professor, University Department of Forensic Sciences, University of Split; Faculty of Law, University of Mostar and attorney-at-law): damir.primorac@primorac-partners.com.

** Dr. sc. Maja Buhovac, odvjetnička stručna suradnica (attorney professional assistant): buhovac.maja@ gmail.com.

${ }^{* * * *}$ Marko Pilić, mag. forens., Sveučilišni odjel za forenzične znanosti Sveučilišta u Splitu, doktorand na Poslijediplomskome doktorskom studiju Međunarodni odnosi Sveučilišta u Zadru i Libertas međunarodnog sveučilišta u Zagrebu (University Department of Forensic Sciences University of Split, Ph.D. student at Postgraduate Studies of International Relations at University of Zadar and Libertas International University Zagreb):mpilic@unist.hr

ORCID ID: orcid.org/0000-0002-4418-9306
} 


\section{UVOD}

Pitanje pravosudne suradnje $u$ kaznenim stvarima već je desetljećima tema pravnih teoretičara i praktičara. Kamen temeljac pravosudne suradnje država članica u kaznenim stvarima proizlazi iz načela uzajamne pravne pomoći i načela uzajamnog priznavanja. Kad je riječ o pravnim izvorima na kojima počiva pravosudna suradnja država članica u kaznenim predmetima, svakako prvo mjesto zauzima Europska konvencija o uzajamnoj sudskoj pomoći u kaznenim stvarima od 20. travnja 1959. godine (dalje u tekstu: Konvencija iz 1959.) ${ }^{1}$ i dodatni protokoli te Konvencije iz 1978. ${ }^{2}$ i 2001. ${ }^{3}$ Navedena Konvencija donesena u okviru Vijeća Europe imala je cilj stvoriti veće jedinstvo država članica prihvaćanjem zajedničkih pravila u području uzajamne sudske pomoći u kaznenim stvarima. U dokaznom pravu dosad je doneseno nekoliko okvirnih odluka kojima je cilj olakšavanje razmjene dokaza. To je ujedno jedan od prioriteta djelovanja Europske unije (dalje u tekstu: EU) u kaznenim stvarima. U tom smislu načelo uzajamnog priznavanja dokaza najvažnije je načelo na kojem počiva razmjena dokaza sa svrhom vođenja kaznenih postupaka u državama članicama, a sve radi stvaranja prostora slobode, sigurnosti i pravde na području EU-a. Ideja o uvođenju europskoga istražnog naloga (dalje u tekstu: EIN) ${ }^{4}$ proizlazi iz Stockholmskog programa ${ }^{5}$ koji je Vijeće prihvatilo 11. prosinca 2009. godine kao rezultat usuglašavanja mišljenja europskih lidera o nužnosti nastavka razvoja sveobuhvatna sustava na području dokaznog prava između država članica, a koji se temelji na načelu uzajamnog priznavanja. ${ }^{6}$ Taj instrument nastao je kao inicijativa sedam država članica EU-a (Kraljevine Belgije, Republike Bugarske, Republike Estonije, Kraljevine Španjolske, Republike Austrije, Republike Slovenije i Kraljevine Švedske) od 23. lipnja 2010. godine, a sve zato što dosadašnji instrumenti pravosudne suradnje u vezi s prikupljanjem dokaza pokazuju da je postojeći okvir previše složen i kompliciran, zbog čega je trebalo posegnuti za sasvim novim pristupom. Razlog je što se Okvirna odluka Vijeća 2003/577/PUP od 22. srpnja 2003. o izvršenju odluka o zamrzavanju imovine i osiguranju dokaza u EU-u (dalje u tekstu: Okvirna odluka iz 2003.) ${ }^{7}$ ograničava samo na fazu zamrzavanja te je potrebno priložiti zaseban

\footnotetext{
1 Europska konvencija o uzajamnoj sudskoj pomoći u kaznenim stvarima, NN-Međunarodni ugovori, br. 4/99.

2 Dodatni protokol Europske konvencije o uzajamnoj sudskoj pomoći u kaznenim stvarima od 17. ožujka 1978. godine, NN-Međunarodni ugovori, br. 4/99.

3 Drugi dodatni protokol uz Europsku konvenciju o uzajamnoj sudskoj pomoći u kaznenim stvarima, NN-Međunarodni ugovori, br. 1/07.

4 Engl. European Investigation Order in criminal matters (EIO).

5 Engl. The Stockholm Programme-An open secure Europe serving and protecting citizens, dostupno na http:// eurlex.europa.eu/legal-content/LT/TXT/PDF/?uri=CELEX:52010XC0504(01)\&from=EN (8. 7. 2018.).

6 Crnčec; Mišerda 2017, 534-535.

7 Engl. Council Framework Decision 2003/577/JHA of 22 July 2003 on the execution in the European Union of orders freezing property or evidence, dostupno na https://eur-lex.europa.eu/legal-content/HR/TXT/?u-
} 
zahtjev za prijenos dokaza u državu donošenja odluke („država izdavateljica”) u skladu s pravilima primjenjivima na uzajamnu pomoć u kaznenim stvarima. To dovodi do postupka u dva koraka koji šteti učinkovitosti. ${ }^{8}$ Ujedno, Direktiva 2014/41/ EU Europskog parlamenta i Vijeća od 3. travnja 2014. godine o europskom istražnom nalogu u kaznenim stvarima (dalje u tekstu: Direktiva) ${ }^{9}$ ne implementira se kao instrument u prekograničnom nadzoru, kako je to navedeno $u$ Konvenciji o provedbi Schengenskog sporazuma. ${ }^{10} \mathrm{~S}$ druge strane, Okvirna odluka Vijeća 2008/978/PUP od 18. prosinca 2008. godine o europskome dokaznom nalogu sa svrhom pribavljanja predmeta, dokumenata i podataka za korištenje u kaznenim postupcima (dalje u tekstu: Okvirna odluka iz 2008.)" donesena je radi primjene načela uzajamnog priznavanja sa svrhom pribavljanja predmeta, dokumenata i podataka za korištenje u postupcima u kaznenim stvarima. Međutim, europski dokazni nalog primjenjuje se samo na već postojeće dokaze, stoga obuhvaća samo dio područja pravosudne suradnje u kaznenim stvarima s obzirom na dokaze. ${ }^{12}$ Prema tome, imajući u vidu da je područje primjene europskoga dokaznog naloga bilo dosta ograničeno, Okvirna odluka iz 2008. godine zamijenjena je Direktivom u odnosu na sve države članice koje obvezuje Direktiva, osim Kraljevine Danske i Republike Irske (to se odnosi i na Okvirnu odluku iz 2003.). ${ }^{13}$

Direktiva je zamijenila odgovarajuće odredbe sljedećih konvencija: Konvenciju iz 1959. godine, kao i njezina dva dodatna protokola, te bilateralne sporazumesklopljene na temelju čl. 26. navedene Konvencije ${ }^{14}$, Konvenciju o provedbi Schengenskog sporazuma i Konvenciju o uzajamnoj pravnoj pomoći u kaznenim stvarima među

$\mathrm{ri}=$ celex\%3A32003F0577 (5. 7. 2018.).

8 Preambula pod 3. Direktive.

9 Engl. Directive 2014/41/EU of the European Parliament and of the Council of 3 April 2014 regarding the European Investigation Order in criminal matters, dostupno na https://eur-lex.europa.eu/legal-content/HR/ TXT/?uri=celex\%3A32014L0041 (5. 7. 2018.).

10 Konvencija o provedbi Schengenskog sporazuma od 14. lipnja 1985. između vlada država Cospodarske unije Beneluksa, Savezne Republike Njemačke i Francuske Republike o postupnom ukidanju kontrola na zajedničkim granicama, Službeni list Europskih zajednica, L. 239/19, 22. 9. 2000., dostupno na https://eur-lex.europa.eu/legal-content/HR/TXT/?uri=celex\%3A42000A0922\%2802\%29 (14. 10. 2018.).

11 Engl. Council Framework Decision 2008/978/JHA of 18 December 2008 on the European evidence warrant for the purpose of obtaining objects, documents and data for use in proceedings in criminal matters, dostupno na https://eur-lex.europa.eu/legal-content/HR/TXT/?uri=CELEX:32008Fo978 (6. 7. 2018.).

12 Preambula pod 4. Direktive.

13 Preambula pod 44. i 45. Direktive te čl. 34., st. 2. Direktive. Vidjeti o tome: Uredba (EU) 2016/95 Europskog parlamenta i Vijeća od 20. siječnja 2016. godine o stavljanju izvan snage određenih akata u području policijske i pravosudne suradnje u kaznenim stvarima. Okvirna odluka iz 2008. stavljena je izvan snage 21. veljače 2016. godine.

14 Europska konvencija Vijeća Europe o uzajamnoj pravnoj pomoći u kaznenim stvarima od 20. travnja 1959. godine, kao i njezina dva dodatna protokola, te bilateralni sporazumi sklopljeni na temelju čl. 26. navedene Konvencije, NN, br. 4/99. 
državama članicama EU-a od 29. svibnja 2000. godine (dalje u tekstu: Konvencija iz 2000.) i protokol uz navedenu Konvenciju..$^{15}$ Dakle, EIN je zamijenio sve tradicionalne oblike međunarodne pravne pomoći (međunarodna pravna pomoć ispitivanjem okrivljenika, vještaka, privremenim oduzimanjem predmeta koji mogu poslužiti pri utvrđivanju činjenica u postupku, provođenjem posebnih dokaznih radnja), osim ustupa odnosno preuzimanja kaznenog progona i zajedničkih istražnih timova (u odnosu na te dokazne radnje i dalje se primjenjuju mjerodavni međunarodni ugovori odnosno Okvirna odluka od 13. lipnja 2002. o zajedničkim istražnim timovima 2002/465/PUP). ${ }^{16}$

$\mathrm{U}$ hrvatsko kazneno zakonodavstvo EIN je uveden u skladu s Direktivom, a implementiran Zakonom o izmjenama i dopunama Zakona o pravosudnoj suradnji u kaznenim stvarima s državama članicama EU-a (dalje u tekstu:Zakon) ${ }^{17} \mathrm{u}$ listopadu 2017. godine. Međutim, područje pravosudne suradnje u okvirima europskog prava izrazito je dinamično i brzo se mijenja, tako da je i sam Zakon dosad mijenjan nekoliko puta. ${ }^{18}$

Osim toga, taj novi institut pravosudne suradnje država članica u kaznenim stvarima otvorio je i neka sporna pitanja koja će ovim radom biti problematizirana te iz kojih će se nastojati izvesti njegovi pozitivni i negativni učinci na pravosudnu suradnju država članica. No prije toga prikazat će se temeljne zakonske odredbe o EIN-u kao rezultat implementacije Direktive u pravni sustav RH.

\section{OPSEG I SADRŽAJ EIN-A}

EIN se zasniva na načelu uzajamnog priznavanja kao temelj pravosudne suradnje u kaznenim predmetima, što znači da između država članica mora postojati visoka razina povjerenja. Upravo postojanjem EIN-a državama članicama osigurava se brži pristup zatraženim dokazima i učinkovitija borba protiv kriminaliteta jer je svaka država članica, ako su za to ispunjeni uvjeti, obvezna priznati i provesti odluku druge države članice, kao što bi to učinila da je u pitanju odluka njezina pravosudnog tijela. Osim toga, cilj19 je tog instrumenta i pojednostavnjenje postupka, održavanje visoke

\footnotetext{
${ }_{15}$ Konvencija o uzajamnoj pravnoj pomoći u kaznenim stvarima među državama članicama EU-a i protokol uz navedenu Konvenciju (COM/2014/0685 final - 2014/0321 (NLE)).

16 Hržina 2018, 17-18.

17 Zakon o pravosudnoj suradnji u kaznenim stvarima s državama članicama Europske unije, NN, br. 91/10, 81/13, 124/13, 26/15, 102/17, 68/17 i 68/18.

18 Prije stupanja na snagu 2013. godine Zakon je ponajprije mijenjan sa svrhom implementacije Okvirne odluke 2009/829/PUP od 23. listopada 2009. godine o primjeni načela uzajamnog priznavanja odluka o mjerama nadzora među državama članicama Europske unije kao alternative privremenom pritvoru, a 2015. implementirana je i Direktiva 2011/99/EU Europskog parlamenta i Vijeća od 13. prosinca 2011. godine o europskom nalogu za zaštitu; Crnčec; Mišerda, 526.

19 Vidjeti i kod Klimek 2012, 280-281.
} 
razine zaštite ljudskih prava (osobito procesnih), smanjenje financijskih troškova i očuvanje specifičnostinacionalnih sustava i njihove pravne kulture. ${ }^{20}$ Upravo suciljevi uvođenja EIN-a pitanja o kojima se najviše raspravlja među pravnim teoretičarima i praktičarima, no prije toga radom će se prikazati temeljne zakonske odredbe koje čine sadržaj i opseg EIN-a.

EIN se prema čl. 2., toč. 9. Zakona definira kao „odluka koju izdaje ili potvrđuje nadležno pravosudno tijelo države članice radi izvršenja jedne ili više dokaznih radnji u drugoj državi članici, odnosno radi pribavljanja već postojećih dokaza od druge države članice" u svim stadijima kaznenih i prekršajnih postupaka, a prema pravilima domaćeg prava. Primjedba ${ }^{21}$ toj odredbi nalazi se $u$ nedefiniranosti „nadležnoga pravosudnog tijela“ za izdavanje EIN-a, osobito što se pod nadležnim tijelom u nekim državama članicama podrazumijeva i policija. ${ }^{22}$ Međutim, Sud EU-a utvrdio je da se izraz "pravosudno tijelo“ ne može tumačiti na način da se njime obuhvaća policija ili izvršno tijelo države članice, kao što je ministarstvo, te da se akti koje su izdala ta tijela ne mogu smatrati "sudskim odlukama“. ${ }^{23}$ Kako pravilno uočava Sayers ${ }^{24}$, potrebno je osigurati neovisnost vođenja kaznenog postupka, a prema takvoj odredbi tijelo koje izdaje EIN identično je onom koje zahtijeva provođenje određene dokazne radnje. Također, postavlja se pitanje kakva je sudska priroda tijela koje izvršava EIN? Dakle, na objema stranama trebala bi se osigurati sudska kontrola provođenja istraga sa svrhom poštivanja temeljnih ljudskih prava i pravilno razmatranje razloga za odbijanje EIN-a.

Takva odredba rezultat je različitosti proceduralnih norma nacionalnih sustava. $U$ skladu s čl. 1., st. 1. Direktive stava smo da EIN jest sudska odluka (u slučajevima kad se EIN izdaje za posebne dokazne radnje). Osim toga, EIN-om se traži provođenje dokaznih radnja koje u većini nacionalnih sustava podliježu sudskom odobrenju. ${ }^{25}$ Tako se omogućava i zaštita temeljnih ljudskih prava na način da se pojedinci ne podvrgavaju nekontroliranim dokaznim mjerama koje može odobriti i policijsko tijelo. ${ }^{26} \mathrm{U}$ čl. 42.b Zakona naglašeno je da sud i državno odvjetništvo izdaju EIN, bez razlike u vrsti dokaznih radnja kako to postoji u domaćemu kaznenom procesnom

\footnotetext{
20 Mangiaracina 2014, 113; Klimek 2012, 280.

21 Mangiaracina 2014, 123-124.

22 Klimek 2012, 281-282.

23 Vidjeti presude Suda EU-a u predmetima C-452/16, PPU Poltorak i C-477/16, Kovalkovas od 10. studenog 2016., dostupno na https://eur-lex.europa.eu/legal-content/HR/TXT/HTML/?uri=CELEX:62016C]0452\&from=HR i https://eur-lex.europa.eu/legal-content/HR/TXT/HTML/?uri=CELEX:62016Cl0477\&from=HR (21. 5. 2019.).

24 Sayers 2011, 9.

25 lbid.

${ }^{26}$ Tako JUSTICE smatra da policijska tijela nisu u dovoljnoj mjeri objektivna, neovisna i pravno kvalificirana za odlučivanje hoće li EIN biti izdan za prikupljanje dokaza u drugoj državi članici, Briefing on the European Investigation Order (August 2010). JUSTICE, London, para. 19, 8.
} 
zakonodavstvu. Dakle, tu odredbu potrebno je restriktivnije regulirati s jasnom distinkcijom za koje dokazne radnje EIN izdaje državno odvjetništvo, a za koje sud.

Zakonskim je tekstom u čl. 42.a, st. 2. posebno istaknuto za koje se države i na koje radnje prikupljanja dokaza taj oblik pravosudne suradnje ne primjenjuje. Naime, iz punog naziva Zakona jasno proizlazi kako se njime regulira pravosudna suradnja u kaznenim stvarima sa svim državama članicama EU-a. Međutim, iz navedene odredbe proizlazi da se EIN ne može izdati sa svrhom osnivanja zajedničkoga istražnog tima i prikupljanja dokaza u takvu timu te provođenja dokaznih radnja u Danskoj i Irskoj. Razlog je što te dvije države imaju trajno drukčiji status glede zakonodavnih akata u području pravosudne suradnje. ${ }^{27}$

EIN se prema već ustaljenoj praksi u okviru pravosudne suradnje, a kako propisuje čl. 42.b Zakona, izdaje "na propisanom obrascu koji je sastavni dio ovog Zakona“ te on mora sadržavati Zakonom propisane podatke. Prema čl. 42.e Zakona EIN se prosljeđuje neposredno nadležnom tijelu izvršenja ili preko kontaktnih točaka Europske pravosudne mreže kaznenim stvarima. Zanimljivo je da se prema čl. 42.b, st. 2. Zakona EIN izdaje i na zahtjev okrivljenika i/ili njegova branitelja koji mogu zatražiti izdavanje EIN-a radi prikupljanja dokaza na području država članica, a sve u skladu s odredbama domaćeg prava. Kako navode Crnčec i Mišerda, namjera europskog zakonodavca očito je bila da se takvom odredbom oživotvorenjem načela jednakosti oružja između stranaka u kaznenom postupku balansiraju mogućnosti obrane i optužbe, koja uspostavljenim mehanizmima prekograničnog prikupljanja dokaza puno lakše dolazi do potrebnih dokaza od obrane. ${ }^{28}$ Međutim, nejednakost oružja između stranaka uočena je u drugim segmentima o kojima će biti više riječi u nastavku rada.

Clede uvjeta izdavanja EIN-a, Zakon u čl. 42.c izričito navodi nužnost i razmjernost postupka te da zatražena dokazna radnja ili radnje navedene $u$ EIN-u mogu biti određene u tom postupku. ${ }^{29}$ Načelo razmjernosti u prvotnom prijedlogu Direktive nije bilo zamišljeno kao uvjet za izdavanje EIN-a, a Winter smatra da ukidanje upućivanja na načelo razmjernosti ne vodi nikakvim relevantnim promjenama jer se pretpostavlja da će svako pravosudno tijelo provjeriti te uvjete prije izdavanja

\footnotetext{
${ }_{27}$ Riječ je o opciji opt out koju su zatražile Velika Britanija, Kraljevina Danska i Republika Irska. Dok je Velika Britanija odlučila iskoristiti mogućnost opt in u vezi s primjenom te Direktive, odnosno da je primjenjuje i bude obvezna postupati po njoj, Irska nije iskoristila navedenu mogućnost, stoga se EIN ne može izdati u odnosu na Irsku. Još je složenija situacija s Danskom, koja ima trajni opt out, odnosno nema uopće mogućnost odlučiti da primjenjuje taj oblik pravosudne suradnje, tako da u odnosu na te dvije države i dalje ostaju na snazi svi postojeći oblici pravosudne suradnje i međunarodne pravne pomoći. Crnčec; Mišerda 2017, 535-536.

${ }_{28}$ Ibid., 537.

29 Čl. 42.c Zakona. Direktiva navodi u čl. 6., st. 1. toč. a) da se pri izdavanju EIN-a trebaju uzeti u obzir i prava osumnjičenika ili okrivljenika.
} 
EIN-a. ${ }^{30}$ Kako uočava Mangiaricana, iskustvo s europskim uhidbenim nalogom (dalje u tekstu: EUN) čiji tekst ne sadržava nijednu odredbu o razmjernosti u izdavanju EUN-a, nije pokazalo propust njegova nepostojanja kao uvjeta, štoviše, pokazalo je da se zemlje poput Poljske prekomjerno koriste EUN-om za "trivijalne zločine“..31 U vezi s tim, Vijeće je utvrdilo da države članice prije negoli se odluče izdati EUN trebaju razmotriti razmjernost procjenjujući niz okolnosti poput ozbiljnosti kaznenog djela, mogućnosti da se osumnjičeni nalazi u pritvoru, vjerojatnu kaznu koja će se izreći ako se tražena osoba proglasi krivom za predmetno kazneno djelo i slično. Osim toga, treba uzeti u obzir i osiguranje učinkovite zaštite javnosti i uvažavanje interesa žrtava kaznenog djela. U tom smjeru, pri donošenju Direktive propisan je uvjet izdavanja EIN-a, gdje načelo razmjernosti ima glavnu ulogu pri procjeni njegova izdavanja. Načelo razmjernosti ${ }^{32}$ propisano je $u$ uvodnim odredbama Zakona ${ }^{33}$, a kako navode Crnčec i Mišerda, cilj mu je da se usmjere tijela koja primjenjuju Zakon u primjeni i tumačenju pojedinih odredaba tog Zakona. ${ }^{34}$ Ocjenu o razmjernosti i nužnosti donosi država izdavanja, no određene ovlasti pri procjeni razmjernosti ima i država izvršenja. Unatoč nastojanju da suradnja između pravosudnih tijela država članica u EU-u bude u što većoj mjeri olakšana i ubrzana, ipak se zatražena radnja može u određenim situacijama izmijeniti, pa čak i odbiti iz razloga koji su odraz primjene načela locus regit actum. Riječ je o situaciji kada:

- „nadležno pravosudno tijelo može provesti dokaznu radnju koja je po svojoj prirodi blaža od radnje navedene u EIN-u ako bi se tom dokaznom radnjom postigao isti rezultat" te

- „nadležno pravosudno tijelo može provesti dokaznu radnju različitu od one navedene $u$ EIN-u ako: a) dokazna radnja navedena u EIN-u ne postoji prema domaćem pravu; ili b) dokaznu radnju navedenu u EIN-u ne bi bilo moguće odrediti u usporedivom domaćem predmetu. ${ }^{{ }^{35}}$

S obzirom na pravilo gdje u specifičnim okolnostima pravosudno tijelo koje izvršava EIN može izmijeniti zatraženu dokaznu radnju drugom, ako ona ne postoji u domaćem pravu ili se ne može odrediti u usporednome domaćem postupku, određena je i iznimna situacija. Iznimka od tog pravila odnosi se na strogo definirane dokazne radnje koje će se uvijek provesti. U skladu s čl. 42., st. 2. Zakona strogo su definirane radnje: a) pribavljanje informacija ili dokaza koji su već u posjedu nadležnih tijela RH ili onih koje su sadržane u bazama podataka koje vodi policija ili pravosudna tijela i izravno su dostupne pravosudnom tijelu izvršenja u okviru kaznenog postupka, b)

\footnotetext{
30 Bachmaier Winter 2010, 584-585.

31 Vogel; Spencer 2010, 481-482.

32 Mangiaracina 2014, 125-126.

33 Čl. 3.a Zakona.

34 Crnčec; Mišerda 2017, 537.

35 Čl. 42.i, st. 1. i 3. Zakona.
} 
radnje ispitivanja osoba, bilo koja dokazna radnja koja se prema domaćem pravu provodi bez sudskog naloga te podatci o identitetu osoba koje imaju pretplatu na određeni telefonski broj ili IP-adresu.

Međutim, prema čl. 42., st. 5. Zakona, u situacijama kada zatražena dokazna radnja navedena $u$ EIN-u ne postoji u domaćem pravu ili je ne bi bilo moguće odrediti $u$ usporedivu domaćem predmetu i ako ne postoji nijedna druga dokazna radnja koja bi imala isti rezultat kao zatražena dokazna radnja, nadležno pravosudno tijelo obavještava tijelo izdavanja da ne može osigurati zatraženu pomoć. ${ }^{36}$ Tako regulirana mogućnost odbijanja pružanja zatražene pravne pomoći izgleda kao jedan od razloga za odbijanje izvršenja EIN-a, odvojen od onih koji postoje u čl. 42.j Zakona. Osim toga, te odredbe povlače za sobom pitanje dopustivosti dokaza ${ }^{37}$ jer ako EIN izdaje nadležno tijelo države izdavateljice prema pravilima njezina domaćeg prava, to bi značilo da država izdavateljica u EIN-u određuje i radnje i metode za traženje i prikupljanje dokaza. Osim toga, država izvršiteljica može odbiti izvršiti EIN ako dokazna radnja ne postoji u domaćem pravu, što znači da država izvršiteljica može po vlastitom nahođenju primijeniti dokaznu radnju, štoviše, ako ne postoji alternativna mjera, može odbiti pružiti pomoć, o čemu obavještava državu izdavateljicu. Na prvi pogled rekli bismo da se takvim alternativnim postupanjem nastojalo ojačati načelo uzajamnog priznavanja, no to baš nije tako, osobito što prema st. 19. Preambule Direktive stoji da ako postoje utemeljeni razlozi za sumnju da bi izvršenje neke istražne mjere navedene $u$ EIN-u prouzročilo kršenje temeljnog prava dotične osobe te da bi država izvršiteljica zanemarila svoje obveze u vezi sa zaštitom temeljnih prava priznatih u Povelji, izvršenje EIN-a trebalo bi odbiti. Stoga bi mogućnost države izvršiteljice da provede dokaznu radnju različitu od one navedene u EIN-u prema pravilima svoga domaćeg prava mogla dovesti u pitanje smisao dokaza za državu izdavateljicu, ako tako pribavljeni dokazi nisu dopušteni u nacionalnom pravu države izdavateljice. ${ }^{38}$ Primjerice, u slučaju da se EIN izdaje radi pretrage doma, država izdavateljica nadležna je za odlučivanje o nužnosti provođenja te dokazne radnje. Međutim, modalitet pretraživanja bit će uređen nacionalnim pravom države izvršiteljice. Ako je pretraga doma moguća noću u državi izdavateljici, ali ne u državi izvršiteljici, Zakon i Direktiva daju mogućnost da država izvršiteljica provede pretraživanje danju u skladu s vlastitim zakonodavstvom. Činjenica da se modaliteti provedbe EIN-a rade prema pravu države izvršiteljice može stvoriti problem u smislu dopustivosti dokaza u državi izdavateljici. ${ }^{39}$ Stoga, radi osiguranja učinkovite pravosudne suradnje država članica u kaznenim stvarima glede izdavanja i izvršenja EIN-a, država izdavateljica mora navesti kako dokazne radnje trebaju biti izvršene

\footnotetext{
${ }_{36}$ Crnčec; Mišerda 2017, 538-539.

37 Vidjeti infra, 19 i dalje.

${ }^{38}$ Navickate 2016, 113.

39 Klimek 2012, 284-285.
} 
da bi pribavljeni dokazi bili zakoniti prema njezinu nacionalnom zakonodavstvu, a država izvršiteljica, nakon što uoči odstupanja u svome nacionalnom pravu, poduzeti korake, nastojeći provedbu EIN-a prilagoditi regulativi države izdavateljice, naravno, sve dok izvršenje EIN-a nije u suprotnosti s nacionalnim pravom države izvršiteljice.

Vezano uz pitanje izdavanja EIN-a, potrebno je istaknuti kako prema Direktivi ovlaštene osobe mogu osporavati u državi izdavanja postojanje pretpostavaka za izdavanje EIN-a (izdavanje EIN-a nužno je i razmjerno svrsi postupka i ispunjene su pretpostavke za provođenje zatražene dokazne radnje u domaćem postupku). ${ }^{40}$

Zakon je u čl. 42.j propisao i razloge za nepriznavanje ili neizvršenje EIN-a te prema ustaljenoj praksi razlikuje fakultativne razloge za odbijanje, odnosno slučajeve $u$ kojima nadležno pravosudno tijelo može odlučiti hoće li izvršiti ili odbiti priznanje, a to su: postojanje imuniteta ili povlastica ako je riječ o djelima koja se tiču slobode medija ili slobode izražavanja te kada se traži provođenje takve vrste dokazne radnje koja se u domaćim postupcima ne bi mogla odrediti. Obligatorni su razlozi za odbijanje, odnosno slučajevi u kojima nadležno pravosudno tijelo neće priznati i izvršiti europski istražni nalog: interesi nacionalne sigurnosti, načelo ne bis in idem, kada je djelo počinjeno na teritoriju RH, a ne postoji dvostruka kažnjivost, ako izvršenje dokazne radnje navedene u EIN-u ne bi bilo u skladu s obvezama iz čl. 6. Ugovora o EU-u i Poveljom o temeljnim pravima EU-a, nepostojanje dvostruke kažnjivosti, osim za 32 kataloška kaznena djela te ako se takva radnja ne bi mogla provesti u domaćem postupku za takvo djelo. Pitanje razloga za nepriznavanje i neizvršenje EIN-a u stručnoj javnosti izazvalo je, rekli bismo, najviše rasprave, o čemu će više riječi biti u nastavku rada.

Kad je riječ o dokaznim radnjama (istražnim mjerama) za koje se može izdati EIN, Zakon u posebnom poglavlju navodi sljedeće dokazne radnje: a) premještaj u RH ili iz nje osoba kojima je oduzeta sloboda radi provođenja dokazne radnje, b) ispitivanje preko videokonferencije ili druge vrste audiovizualnog prijenosa, c) ispitivanje svjedoka ili vještaka preko telefonske konferencije, d) pribavljanje podataka o bankovnim i drugim financijskim računima, e) pribavljanje podataka o bankovnom i drugom financijskom poslovanju, f) provedba dokazne radnje prikupljanja dokaza u realnom vremenu, g) neprekidno i tijekom određenog razdoblja, h) uporaba prikrivenih istražitelja, i) nadzor telekomunikacija uz tehničku pomoć druge države članice, j) privremeno oduzimanje predmeta. Kod provođenja pojedinih dokaznih radnja pojavljuju se određena pitanja koja su rezultat različitih nacionalnih sustava i načina postupanja prema sudionicima istražnog postupka. Naime, kad je riječ o razlozima za odbijanje izvršenja EIN-a, osim razloga iz čl. 42.j Zakona, uočavamo da postoje i drugi razlozi na temelju kojih se može odbiti izvršenje EIN-a koji nisu obuhvaćeni čl. 42.j Zakona. Tako

40 Hržina 2018, 19. 
kod provođenja predaje privremeno zadržane osobe država izvršiteljica može odbiti EIN izdan zbog premještaja ako pritvorena osoba ne pristane na to. Slična je situacija i kod provođenja ispitivanja preko videokonferencije ili druge vrste audiovizualnog prijenosa. Ako osumnjičenik ili okrivljenik nije suglasan ili ako bi izvršenje takve dokazne radnje u određenom slučaju bilo u suprotnosti s temeljnim načelima domaćeg prava, država izvršiteljica može odbiti izvršenje EIN-a. Zakon i Direktiva ovdje daju mogućnost državi izvršiteljici da odbije EIN, što ostavlja dovoljno prostora za razvoj načela uzajamnog priznavanja, u cilju stvaranja prostora slobode, sigurnosti i pravde.

$S$ druge strane, kad je riječ o dokaznim radnjama pribavljanja podataka o bankovnim i drugim financijskim računima, uočavamo da država izdavateljica EIN-a mora navesti detaljne i jasne informacije koje se traže te razloge zašto smatra da bi zatraženi podatci mogli biti važni za domaći kazneni postupak. S obzirom na to da se te dokazne radnje mogu poduzeti ne samo protiv osumnjičenika nego i drugih pravnih i fizičkih osoba, mišljenja smo da država izvršiteljica ima pravo inzistirati na detaljnim informacijama o provođenju tih dokaznih mjera kako bi im se spriječilo nekontrolirano podvrgavanje pojedinaca.

Još je jedno pitanje regulirano Zakonom, a tiče se provođenja dokaznih radnja sadržanih u EIN-u, da država izvršiteljica jamči tajnost podataka i zahtjeva iz EIN-a u skladu sa svojim nacionalnim pravom..$^{41}$ Dakle, ako država izvršiteljica ne može osigurati tajnost istrage u skladu sa svojim nacionalnim pravom, tumačeći odredbe Zakona, ostaje joj mogućnost da odbije izvršiti EIN. To može prouzročiti poteškoće u suradnji država članica zbog različitosti u procesnim odredbama nacionalnih sustava vezanih za istragu. Osim toga, države članice (država izdavateljica i država izvršiteljica) moraju osigurati pravna sredstva koja se mogu primijeniti u slučajevima odbijanja EIN-a, barem sličnim pravnim lijekovima koji postoje u nacionalnim pravnim sustavima država članica. Zakon je propisao u čl. 42m da na rješenje kojim sud odbije priznati i izvršiti EIN državni odvjetnik ima pravo žalbe u roku od tri dana. Međutim, sobzirom na to da izdavanje EIN-a može zatražiti i osumnjičenik, odnosno njegov odvjetnik, Zakon ne predviđa mogućnost pravnog lijeka u slučaju odbijanja EIN-a čije je izdavanje tražio osumnjičenik. Na taj način ogleda se nejednakost oružja stranaka u istražnom postupku.

\subsection{EIN i drugi instrumenti pravosudne suradnje u kaznenim stvarima}

Kao što je već navedeno, EIN je nastao kao rezultat potrebe uspostavljanja sveobuhvatna sustava za pribavljanje dokaza u prekograničnim predmetima na temelju načela uzajamnog priznavanja. Razlog je što je sustav postojećih instrumenata u tom području rascjepkan teje potreban nov pristup kojiće se temeljiti

${ }^{41}$ Čl. $42 . s$ Zakona. 
na načelu uzajamnog priznavanja, ali koji će ujedno uzimati u obzir fleksibilnost tradicionalnog sustava uzajamne pravne pomoći. Dosadašnji instrumenti nastali Okvirnim odlukama Vijeća iz 2003. i 2008. upozorili su na određene manjkavosti. Tako je Okvirnom odlukom iz 2003. predviđeno rješavanje pitanja nužnosti hitna uzajamnog priznavanja odluka kako bi se spriječilo uništavanje, mijenjanje, prebacivanje, prijenosili uništavanje dokaza, s time da je taj instrument bio ograničen samo na stadij zamrzavanja. ${ }^{42} \mathrm{~S}$ druge strane, Okvirna odluka iz 2008. godine donesena je radi primjene načela uzajamnog priznavanja sa svrhom pribavljanja predmeta, dokumenata i podataka za korištenje u postupcima u kaznenim stvarima. Međutim, europski dokazni nalog ${ }^{43}$ odnosi se samo na već postojeće dokaze te stoga obuhvaća samo dio područja pravosudne suradnje u kaznenim stvarima s obzirom na dokaze. Najvažnija je novost da se europskim nalogom za pribavljanje dokaza ne nalaže državi da poduzme određenu dokaznu radnju, nego samo da pribavi dokaz dokaznom radnjom koju će sama odabrati i koja najviše odgovara uvjetima njezina nacionalnog prava. Time je državi izvršenja naloga omogućena prilagodba posebnostima njezina kaznenoga procesnog prava. ${ }^{44}$ Zbog njegova ograničenog područja primjene nadležna tijela mogla su se služiti novim sustavom ili postupcima uzajamne pravne pomoći koji se u svakom slučaju primjenjuju na dokaze izvan područja primjene europskoga dokaznog naloga. ${ }^{45}$ Osim navedenih instrumenata pravosudne suradnje, EIN ima određene sličnosti i razlike is EUN-om te zajedničkim istražnim timom (engl. Joint Investigation Team - dalje u tekstu: ZIT). ${ }^{46}$

Prvi instrument za provedbu načela uzajamnog priznavanja bio je EUN koji je zamijenio izručenje ${ }^{47} \mathrm{~s}$ pojednostavnjenim sustavom predaje između sudskih vlasti. lako taj instrument dobro funkcionira, iskustvo je pokazalo nekoliko problema kao posljedicu razlika procesnih sustava. ${ }^{48}$ Neka su od tih pitanja ukidanje dvostruke kažnjivosti za kaznena djela s popisa kaznenih djela, predaja vlastitih državljana, stupanj automatizma i stupanj do kojeg se može odbiti izvršenje EUN-a, kao i utjecaj priznavanja ljudskih prava. ${ }^{49} \mathrm{O}$ sim toga, posebne kritike odnosile su se na nedostatak

\footnotetext{
${ }^{42}$ Imajući u vidu da je taj instrument bio ograničen samo na stadij zamrzavanja, odluci o zamrzavanju treba biti priložen zaseban zahtjev za prijenos dokaza u državu izdavateljicu, u skladu s pravilima primjenjivima na uzajamnu pomoć u kaznenim stvarima. Dakle, to dovodi do postupka u dva koraka koji šteti učinkovitosti. Nadalje, osim tog instrumenta postoje i tradicionalni instrumenti suradnje, zbog čega ga nadležna tijela rijetko primjenjuju u praksi. (Preambula pod 3. Direktive).

${ }_{43}$ O europskome dokaznom nalogu vidjeti i Klimek 2012, 265 i dalje.

44 Burić; Hržina 2014, 359-361.

45 Preambula pod 4. Direktive.

${ }^{46}$ Engl. Council Framework Decision 2002/465/JHA of 13 June 2002 on joint investigation teams, Službeni list Europske unije O] L 162, 20. 6. 2002., dostupno na https://www.europol.europa.eu/activities-services/ joint-investigation-teams (18. 7. 2018.).

47 Primorac 2018, 21-22.

${ }^{48}$ Više o tome vidjeti JUSTICE 2012, 22.

49 Mitsilegas 2009, 538.
} 
procjene razmjernosti EUN-a od tijela koje ga je izdalo. S druge strane, Direktiva je uvela kao uvjet izdavanja EIN-a načelo razmjernosti i nužnosti. Zajedničko je u ta dva instrumenta pravosudne suradnje načelo uzajamnog priznavanja koje se zasniva na uzajamnom povjerenju kao preduvjetu za njegovo funkcioniranje. Također, kod obaju instrumenata uočavamo nepostojanje zajedničkih proceduralnih pravila između država članica kojima bi se omogućilo olakšavanje provođenja dokaznih radnja, dopustivost i zakonitost dokaza u državi članici te na taj način stvaranje prostora slobode, sigurnosti i pravde.

Kad je riječ o odnosu EIN-a sa ZIT-om, rekli bismo da je EIN klasični instrument pravosudne suradnje jer je riječ o bilateralnom odnosu prikupljanja dokaza između države izdavateljice EIN-a i države izvršiteljice EIN-a. S druge strane, ZIT je sastavljen na temelju sporazuma dviju ili više država članica $E U-a^{50}$ za određenu namjenu i na određeno vrijeme, s time da ZIT, ako treba pravnu pomoć od treće države (dakle, države koja nije država članica EU-a), može ju zatražiti od nadležnih tijela te države. ${ }^{51}$ Također, razlika se ogleda i u mogućnosti uključivanja predstavnika države izdavateljice ElN-a u provođenju dokaznih radnja u državi izvršiteljici. Zakon predviđa mogućnost njihove nazočnosti pri njihovu provođenju ako to nije u suprotnosti s temeljnim načelima domaćega pravnog poretka niti šteti bitnim interesima nacionalne sigurnosti $\mathrm{RH} .{ }^{52}$ Predstavnik države izdavateljice nema ovlasti samostalno poduzimati dokazne radnje, osim ako je to u skladu s domaćim pravom, te ako to nije dogovoreno s državom izvršiteljicom. Dakle, njihova je mogućnost sudjelovanja u samome istražnom postupku u državi izvršiteljici dosta ograničena. $S$ druge strane, ZIT-ovi alati za prikupljanje dokaza nude puno više mogućnosti za uključivanje u operativne aktivnosti „članovima zajedničkog istražnog tima iz država članica koje nisu države članice u kojima tim djeluje ${ }^{\text {us3 }}$, tzv. dodijeljeni članovi. ZIT se, između ostalog, razlikuje od EIN-a po tome što preko njega države članice ZIT-a izravno razmjenjuju informacije bez slanja formalnog zahtjeva, zahtijevaju provođenje dokaznih radnja izravno, bez dostavljanja naloga itd. ${ }^{54}$

Zaharieva navodi ilustrativan primjer kojim pokazuje prednosti i nedostatke EIN-a komparirajući ga sa ZIT-om ${ }^{55}$ te zaključuje da EIN omogućava da se dokazne radnje provedu u jasno definiranim i relativno kratkim rokovima. Navodi kako se EIN-

\footnotetext{
50 Prema čl. 12.I Zakona zajednički istražni tim osniva se u sljedećim slučajevima: zbog opsežnih i složenih istraga kaznenih djela koja uključuju suradnju s drugim državama članicama te kad nadležna tijela jedne ili više država članica provode istraživanje kaznenih djela čije okolnosti zahtijevaju usklađeno i koordinirano zajedničko djelovanje nadležnih tijela uključenih država.

${ }^{51}$ Vidjeti čl. 8. Okvirne odluke Vijeća Europske unije od 13. lipnja 2002. godine o zajedničkim istražiteljskim ekipama (2002/465/PUP), (SL L 162, 20. 6. 2002.) te čl. 12.t. Zakona.

${ }_{52}$ Čl. 42.h, st. 4. Zakona.

53 Čl. 13., st. 4. Konvencije iz 2000.

54 Petrić 2009, 532-533.

55 Zaharieva 2017, 404-405.
} 
om omogućava centralizacija slučaja gdje je razvijanje strategije istrage potpuno u rukama jedne države koja preuzima obvezu daljnjeg progona. Nedostatak je EIN-a u jednostavnim ilustrativnim slučajevima nepostojanje ZIT-a jer država djeluje samo u granicama zahtjeva koji je zadala druga država. Tako navodi da je zbog prekoračenja zahtjeva iz EIN-a država izvršiteljica ovlaštena odbiti izvršiti EIN, što utječe na učinkovitost suradnje država članica. ${ }^{56} \mathrm{Kad}$ je riječ o troškovima, činjenica je da je prekogranična suradnja iznimno skupa jer zahtijeva iznimno visoka financijska sredstva za provođenje dokaznih radnja sa svrhom istraživanja složenoga transnacionalnog kriminaliteta. Ti troškovi jednako su skupi i kod ZIT-a jer obuhvaćaju aktivnu razmjenu informacija i dokaza, povećanu komunikaciju između članova ZIT-a, troškove prevođenja, putovanja, smještaj članova i sl. Međutim, bitna je razlika između tih dvaju instrumenta glede troškova što kod ZIT-a, nasuprot EIN-u, postoji mogućnost dobivanja sredstava EU-a. Primarno je ta mogućnost postojala u okviru programa ISEC kojim upravlja Komisija, a sada se ZIT-ovi mogu izravno financirati preko Eurojusta ili preko potpore EMPACT kojim upravlja Europol.57

\section{SPORNA PITAN]A PRIMJENE EIN-A}

Premda je cjelovit tekst inicijative o uvođenju EIN-a izazvao široke rasprave ${ }^{58}$ o pitanjima poput osiguranja temeljnih ljudskih prava, procesnih prava pojedinaca te utjecaj EIN-a na nacionalnu suverenost, Direktivom je taj instrument postao dio pravnog sustava EU-a. Bez obzira na to što implementacija EIN-a u pravnu stečevinu EU-a te nacionalna zakonodavstva njezinih država članica ima cilj poboljšanje i učinkovitiju suradnju na području dokaznog prava, a sve sa svrhom što bržeg otkrivanja i procesuiranja počinitelja kaznenih djela, od same inicijative do implementacije EIN-a kaznenopravna javnost spori o načelima kojima se njegovo provođenje protivi. To su pitanja osiguranja temeljnih ljudskih prava niza sudionika u tom stadiju postupka te zanemarivanje procesnih prava pojedinaca u kaznenom postupku, popis razloga za odbijanje i neizvršenje EIN-a, dopustivost i zakonitost dokaza i sl. Dosadašnjom analizom utvrđeno je da svi instrumenti pravosudne suradnje imaju određene manjkavosti, no s obzirom na kompleksnost materije i postupanja treba tražiti modalitete njegove primjene i prilagodbe $u$ kaznenopravnim sustavima država članica.

Za dokazno pravo EU-a često se navodi da je u pitanju „kamen spoticanja“ uspješnoj pravosudnoj suradnji u kaznenim stvarima. Razlog je za to dvojak. Kao prvo, postoje znatne razlike između europskoga kontinentalnog i anglosaksonskoga dokaznog

\footnotetext{
56 Ibid., 406.

57 Ibid., 403.

58 Peers 2010, 1; Bachmaier Winter 2010, 587; Sayers 2011, 15.
} 
prava koje onemogućuju jednostavno transferiranje dokaza iz jednog u drugi sustav. $S$ druge strane, transferiranje dokaza može imati negativne učinke i na pitanje zakonitosti dokaza i ustavnopravna jamstva okrivljenika u kaznenom postupku. Zato ta materija traži stalno usuglašavanje i modificiranje prava EU-a. ${ }^{59}$

\subsection{Zaštita temeljnih ljudskih prava i opseg procesnih prava osumnjičenika primjenom EIN-a}

EU ima cilj stvarati i jačati mehanizme kojima će osigurati prostor slobode, sigurnosti i pravde unutar njezinih granica. I sam EIN ima takav cilj, što potvrđuje $\mathrm{i}$ teza ]. Benthama: "Evidence is the basis of justice: exclude evidence, you exclude justice". ${ }^{60}$ Međutim, kako uočava Winter, EU se bavi jačanjem učinkovitosti kaznenog progona počinitelja kaznenih djela, ali ne vodi usporedno računa o povećanju postupovnih jamstava ${ }^{61}$ za okrivljenike. Kako se god nastoji što učinkovitije dokazati određeno kazneno djelo, također treba voditi brigu o artikulaciji obrane na toj razini. ${ }^{62}$ lakoje cilj EIN-a poboljšati položaj obrane u sustavu uzajamne pravne pomoći, očigledno je da načelo jednakosti oružja ${ }^{63}$ obrane s državnim odvjetnikom nije potpuno osigurano. ${ }^{64}$ Pravo na obranu ustavno je pravo te proizlazi iz niza međunarodnih dokumenata, $u$ prvom redu čl. 6. (Europske) konvencije za zaštitu ljudskih prava i temeljnih sloboda (dalje u tekstu: EKLJP). ${ }^{65}$ Osumnjičenici u domaćemu istražnom postupku imaju određena prava u skladu s odredbama Zakona o kaznenom postupku (dalje u tekstu: ZKP). ${ }^{66}$ Tako je u čl. 239.a ZKP-a propisano da osumnjičenik ima pravo prigovora zbog povrede postupovnih prava obrane u prethodnom postupku. Taj instrument proizlazi iz Odluke Ustavnog suda RH koji je utvrdio da „opseg zahtijevane sudske zaštite u predistražnoj $i$ istražnoj fazi postupka mora obuhvatiti temeljna pitanja zakonitosti prethodnog postupka ... da sudovi moraju provoditi i kontrolu postojanja pretpostavki za kazneni progon i kontrolu zapreka za kazneni progon" te da osoba mora imati mogućnost zahtijevati preispitivanje zakonske osnovanosti progona ako su, primjerice, osnove sumnje utvrđene arbitrarno. Osim toga, ZKP propisuje i mogućnost žalbe protiv rješenja o provođenju istrage, zatim pritužbu

\footnotetext{
59 Vuletić 2016, 82.

60 Klimek 2012, 250.

${ }^{61}$ Navickaite 2016, 114-115.

61 Klimek 2012, 250.

62 Bachmaier Winter, 587.

${ }_{63}$ O načelu vidjeti Cless 2006, 92 i dalje.

${ }^{64}$ Mangiaricana 2014, 123.

${ }^{65}$ Europska konvencija za zaštitu ljudskih prava i temeljnih sloboda, NN-Međunarodni ugovori, br. 18/97, 14/02, 13/03, 9/05, 1/06, 2/10.

${ }^{66}$ Zakon o kaznenom postupku, NN, br. 152/08, 76/09, 80/11, 121/11, 91/12, 143/12, 56/13, 145/13, 152/14, 70/17.
} 
višemu državnom odvjetniku zbog odugovlačenja postupka i drugih nepravilnosti tijekom istrage, prigovor sudcu istrage zbog odugovlačenja postupka i pritužbu zbog nepostupanja suda u zakonskim rokovima u prethodnom postupku. ${ }^{67}$

Bez obzira na to koliko je važno poboljšavati učinkovitost pravosudne suradnje, očuvanje temeljnih ljudskih prava niza sudionika (osumnjičenika, svjedoka, oštećenika) u kaznenom postupku temeljna je zadaća svih država članica. Činjenica je da postoje razlike u proceduralnim odredbama pojedinih kaznenopravnih sustava, no na razini EU-a treba raditi na osiguranju minimalnih pravila ${ }^{68} \mathrm{koja}$ proizlaze i iz samog Ugovora o EU-u. ${ }^{69} \mathrm{U}$ vezi s provedbom EIN-a, Winter uočava i kako malen broj okrivljenika ima dostatna sredstva za organiziranje i plaćanje transnacionalne obrane $^{70}$, što dovodi u pitanje opseg njihovih postupovnih jamstava. ${ }^{71}$ Osim toga, osumnjičenicima je vrlo teško doći do dokaza u drugoj državi članici te provjeriti kako je tužiteljstvo došlo do njih. ${ }^{72}$ Stoga određeni autori predlažu da se omogući obrani prikupljanje dokaza, barem u slučajevima kada se EIN izdaje na inicijativu osumnjičenika, odnosno njegova branitelja. ${ }^{73}$ Osim navedenog, neki autori smatraju da se zbog formalizma odredaba iz Direktive države u bilateralnom odnosu (država izdavateljica i država izvršiteljica EIN-a) nalaze u unaprijed programiranoj situaciji u kojoj će obje strane biti prisiljene povrijediti temeljna ljudska prava ${ }^{74}$ koja proizlaze iz međunarodnih konvencija, u prvom redu čl. 6. EKLJP-a, kao i procjene proporcionalnosti izdanog EIN-a od države izdavateljice, odnosno njegov nedostatak. ${ }^{75}$ Stoga je od iznimne važnosti odredba čl. 6., st. 1., točka a) Direktive (čl. 42.c, st. 1. Zakona) koja navodi da izdavanje EIN-a mora biti razmjerno svrsi postupka uzimajući u obzir prava okrivljenika. Dakle, mora biti riječ o objektivnoj ocjeni da je EIN nužan za provođenje određene dokazne radnje, ali i nakon toga u stadiju kada se EIN izvršava, mora se voditi računa o pravima okrivljenika, svjedoka, zaštitnim mjerama prema njima i sl. U svakom slučaju, vidljivo je da se Direktiva bavi formalnim uvjetima za izdavanje EIN-a sa svrhom prikupljanja dokaza za daljnji kazneni postupak u državi izdavateljici, a ne vodi se dovoljno računa o pravima osoba koje su podvrgnute dokaznim radnjama iz EIN-a, no tek će praktične implikacije upozoriti na nužne izmjene u tom dijelu.

\footnotetext{
67 Vržina 2015, 219-220.

${ }^{68}$ Vidjeti infra, 19 i dalje.

69 Čl. 82., st. 2. Ugovora o EU-u (bivši članak 31. Ugovora o EU-u).

70 Bachmaier Winter 2010, 587.

71 Đurđević 2009, 785-788.

72 Bachmaier Winter 2010, 587.

73 Jurka; Zajančkauskienè 2016, 77; Navickate 2016, 117.

74 Sayers 2011, 12; Staes 2011, 55-56.

75 Mitsilegas 2009, 538.
} 
Treba istaknuti da i sama Direktiva u Preambuli navodi sljedeće: „Prilikom izdavanja EIN-a, tijelo izdavatelj trebalo bi obratiti posebnu pozornost na osiguranje punog poštovanja prava sadržanih u članku 48. Povelje Europske unije o temeljnim pravima Europske unije (Povelja). Pretpostavka nedužnosti i prava na obranu u kaznenom postupku osnova su temeljnih prava priznatih u Povelji u području kaznenog pravosuđa. Svako ograničavanje tih prava putem istražne mjere određene u skladu s ovom Direktivom trebalo bi biti u potpunosti usklađeno sa zahtjevima utvrđenima u članku 52. Povelje s obzirom na nužnost, proporcionalnost i ciljeve koje bi trebalo provoditi, posebno zaštitu prava i sloboda drugih osoba." ${ }^{76}$

Osim toga, ne smije se zaboraviti da je jedna od ključnih odredaba koja jamči temeljna ljudska prava i odredba iz Preambule Direktive, koja navodi da bi Direktivu trebalo provesti uzimajući u obzir Direktivu o pravu na tumačenje i prevođenje $u$ kaznenim postupcima ${ }^{77}$, Direktivu o pravu na informiranje $u$ kaznenom postupku ${ }^{78}$ te Direktivu o pravu na pristup odvjetniku u kaznenom postupku i u postupku na temelju europskoga uhidbenog naloga te o pravu na obavješćivanje treće strane $u$ slučaju oduzimanja slobode i na komunikaciju s trećim osobama i konzularnim tijelima. ${ }^{79}$ Dakle, da bi se osiguralo sprječavanje povrede temeljnih ljudskih prava, EIN se treba odabrati ondje gdje se dokazna radnja čini razmjernom, odgovarajućom i primjenjivom na predmetni slučaj. Između ostalog, država izdavateljica EIN-a dužna je osigurati potpunu usklađenost EIN-a s pravima iz čl. 48. Povelje o temeljnim pravima. $^{80}$

\subsection{Liberalna primjena razloga za nepriznavanje i neizvršenje EIN-a te mogućnost odabira druge mjere}

Najveće kritike dosad vezano za taj instrument pravosudne suradnje izazvale su odredbe o razlozima za nepriznavanje i neizvršenje EIN-a te odredbe o mogućnosti primjene druge mjere od one koja je zatražena EIN-om. S obzirom na to da se pravosudna suradnja temelji na načelu uzajamnog priznavanja ${ }^{81}$,Zaharieva pokazuje kako se doista tvrdilo da je popis razloga u čl. 11. Direktive (čl. 42.j Zakona) preširoko

\footnotetext{
76 St. 12. Preambule Direktive.

77 Direktiva 2010/64/EU Europskog parlamenta i Vijeća od 20. listopada 2010. o pravu na tumačenje i prevođenje u kaznenim postupcima.

78 Direktiva 2012/13/EU Europskog parlamenta i Vijeća od 22. svibnja 2012. o pravu na informiranje u kaznenom postupku.

79 Direktiva 2013/48/EU Europskog parlamenta i Vijeća od 22. listopada 2013. o pravu na pristup odvjetniku u kaznenom postupku i u postupku na temelju europskoga uhidbenog naloga te o pravu na obavješćivanje treće strane u slučaju oduzimanja slobode i na komunikaciju s trećim osobama i konzularnim tijelima.

${ }^{80}$ Navickate 2016, 114-115.

81 Čl. 3. Zakona.
} 
reguliran te da je u suprotnosti s navedenim načelom, štoviše, da se EIN zbog toga nema pravo zvati instrumentom uzajamnog priznavanja. ${ }^{82}$ Stoga zaključuje da bi ti razlozi trebali biti uži od onih koje imamo kod klasičnih instrumenata uzajamne pravne pomoći. Na taj način doprinosi se stvaranju prostora slobode, sigurnosti i pravde, što je i jedan od krajnjih ciljeva EU-a u provođenju instrumenata pravosudne suradnje, ponajviše jer su dokazi rezultat proceduralnih aktivnosti vođenih po specifičnim stručnim i znanstvenim pravilima izakonima ${ }^{83}$ Ona prikazuje ilustrativan primjer provedbe EIN-a i preko njega pokazuje niz problema pri njegovoj provedbi (opseg EIN-a, pitanje troškova, prekoračenje ovlasti u izvršenju EIN-a i sl.). ${ }^{84} \mathrm{~S}$ druge strane, Sayers navodi da su razlozi za odbijanje i izvršenje EIN-a ograničeni, čak i u slučajevima kad slična dokazna radnja ne postoji prema domaćem pravu države izvršiteljice. Međutim, uočava da postoje razlozi za odbijanje EIN-a koji nisu obuhvaćeni čl. 11. Direktive (čl. 42.j Zakona), prije svega, ako je EIN u suprotnosti $s$ temeljnim načelima nacionalnog prava ${ }^{85}$ Određena ograničenja pri izvršenju pojedine dokazne radnje, odnosno mogućnost odbijanja njihova izvršenja moraju postojati, ali mišljenja smo da ti razlozi moraju biti svedeni na minimum, upravo vodeći se načelom uzajamnog priznavanja i povjerenja.

$S$ druge strane, kad je riječ o mogućnosti uporabe druge istražne mjere (dokazne radnje) od one koja je zatražena EIN-om, i tu nailazimo na niz kritika takve odredbe. Primarno, uočava se kontradiktornost odredbe čl. 10. s odredbom čl. 9. Direktive (čl. 42.h, čl. 42.i Zakona). U čl. 9. Direktive propisano je da tijelo države izvršiteljice priznaje EIN bez dodatnih formalnosti, a u čl. 10. Direktive navodi kako tijelo države izvršiteljicemože izvršiti drugu mjeru od onekojajezatražena EIN-om pod određenim uvjetima. Jedni smatraju da mogućnost izvršenja druge mjere vodi fleksibilnosti i jednostavnosti provođenja dokaznih radnja, dok drugi smatraju da takva odredba može stvoriti štetne posljedice u državi izdavanja. ${ }^{86} \mathrm{U}$ tom smislu, Winter navodi da je bitno da se odnosi između država temelje na "slijepom priznanju“ utemeljenu na uzajamnom povjerenju bez mogućnosti da se proturječi izboru postupovnih oblika prikupljanja dokaza. ${ }^{87}$ Svrha EIN-a svakako je fleksibilno i jednostavno prikupljanje dokaza jer je to temelj vođenja odgovarajućih postupaka unutar granica EU-a, pa navedene odredbe Zakona i Direktive omogućuju da države u bilateralnom odnosu pronađu što učinkovitije rješenje u prikupljanju dokaza. U svakom slučaju, mišljenja smo da se pravosudna suradnja između država članica općenito mora zasnivati na visoku stupnju povjerenja, što ne znači da će država izdavanja neograničeno moći

\footnotetext{
82 Zaharieva 2017, 402-403; Sayers, 6; Armada 2015.

${ }^{83}$ Allegrezza 2010, 573.

${ }^{84}$ Zaharieva 2017, 404-405.

85 Sayers 2011, 11; Supra, 10.

${ }^{86}$ Jurka; Zajančkauskiene 2016, 74; Sayers 2011, 11-12; Mangiaricana 2014, 127-128.

${ }^{87}$ Bachmaier Winter 2010, 586.
} 
zahtijevati od države izvršenja provođenje pojedinih dokaznih radnja. Osobito bi to bilo nedopustivo s obzirom na to da troškovi o provođenju EIN-a padaju na državu izvršiteljicu. Osim toga, analizirajući odredbe Zakona, uočavamo da zakonodavac, vodeći se ciljevima iz Direktive, ostavlja dovoljno mogućnosti da države članice razvijaju visok stupanj povjerenja koji je temelj za ostvarivanje načela uzajamnog priznavanja.

\subsection{Troškovi}

Troškovi izdavanja EIN-a, odnosno provođenja pojedine dokazne radnje na području države izvršenja padaju na državu izvršiteljicu. Ako nadležno tijelo države izvršenja smatra da su troškovi izvršenja EIN-a iznimno visoki, može se savjetovati s tijelom izdavanja o tome mogu li se i na koji način troškovi dijeliti ili EIN izmijeniti. U iznimnim situacijama kad se ne može postići suglasnost s državom izvršenja EIN-a u vezi s troškovima, nadležno pravosudno tijelo države izdavateljice može odlučiti da potpuno ili djelomično povuče EIN ili da zadrži EIN i snosi dio troškova koji se smatraju iznimno visokim. Tako regulirano pitanje troškova većje dovelo do znanstvenih rasprava.

Direktiva i Zakon propisuju slučajeve podjele troškova ili izmjene EIN-a, međutim ne reguliraju pitanje kako će se izvršiti EIN ako države ne postignu dogovor u vezi s troškovima. Takva je situacija moguća, osobito ako se uzmu u obzir odstupanja u proračunima kojima raspolažu pravosudna tijela različitih država članica. Nedostatak detaljnijih odredaba o troškovima može dovesti do kašnjenja s izvršenjem EIN-a, što može prouzročiti štetne posljedice za pravosudnu suradnju država članica te pravodobno procesuiranje počinitelja kaznenih djela. ${ }^{88}$ Tako Zaharieva u ilustrativnom primjeru navodi da zbog visokih troškova provođenja pojedinih istražnih radnja, u konkretnom slučaju znatnim prekomjernim radom policijskih službenika koje država izvršenja ne može priuštiti, može doći do zastoja u transferiranju dokaza, u tom slučaju žrtava trgovine ljudima u državu izdavanja EIN-a. ${ }^{89} \mathrm{~S}$ druge strane, imajući u vidu da se izvršenje EIN-a u državi izvršiteljici obavlja zbog vođenja kaznenog postupka u državi izdavanja EIN-a, pravno je logički da troškovi provođenja pojedinih istražnih mjera padaju na državu izdavanja EIN-a, a ne državu izvršiteljicu, kako Zakon nalaže.

\footnotetext{
${ }_{88}$ Zaharieva 2017, 403.

${ }^{89}$ Vidjeti ilustrativan primjer; ibid., 404-405.
} 


\subsection{Uzajamna prihvatljivost dokaza i zajednički minimalni standardi}

EIN je nov instrument pravosudne suradnje čiji je cilj olakšavanje prikupljanja dokaza u kaznenim stvarima u EU-u, za koji se vjeruje da je učinkovitiji od naloga za zamrzavanje imovine i europskoga dokaznog naloga. Međutim, EIN nije oslobođen konceptualnih slabosti koje će ugroziti njegovu prekograničnu učinkovitost. Direktiva, a tako i Zakon, nisu popraćeni pravilima koja olakšavaju uzajamnu prihvatljivost dokaza prikupljenih preko EIN-a, što je ključ za njegovu potpunu učinkovitost. Pitanje kako riješiti dopustivost dokaza prikupljenih u prekograničnoj suradnji već je dugo pitanje unutar EU-a i u kontekstu suradnje Vijeća Europe u kaznenim stvarima..$^{90}$ Konvencija iz 1959. koja je izvorno bila osnova za uzajamnu pravnu pomoć između država članica EU-a temeljila se na načelu locum regit actum (čl. 3. Konvencije iz 1959.) prema kojem je presudan element u određivanju mjerodavnog prava mjesto gdje se nalaze dokazi. Međutim, taj koncept nije u stanju prevladati razlike između nacionalnih postupaka, zbog čega se katkad informacije koje se prikupljaju u državi članici kojoj je zahtjev podnesen ne mogu upotrebljavati u državi moliteljici jer način na koji su informacije dobivene u prvoj ne odgovara nacionalnim proceduralnim zahtjevima potonjeg. Stoga, kako bi se povećale šanse da dokazi prikupljeni u inozemstvu budu prihvatljivi, nova Konvencija iz 2000. pruža nov pristup - načelo forum regit actum (čl. 4. Konvencije iz 2000.). Prema tom načelu zamoljena država članica koja izvršava zahtjev mora udovoljavati formalnostima i postupcima koje je izričito navela država članica koja podnosi zahtjev. Zbog opterećenja koje bi to moglo imati za državu članicu kojojje zahtjev podnesen, država članica koja podnosi zahtjev trebala bi odrediti samo one formalnosti i postupke koji su nužni za njezinu istragu. Zamoljena država može te formalnosti odbiti samo ako su u suprotnosti s njezinim temeljnim pravnim načelima ili ako sama Konvencija iz 2000. izričito navodi da se izvršenje zahtjeva uređuje zakonom države članice kojoj je zahtjev podnesen. lako je načelo forum regit actum bilo temelj za prekograničnu suradnju u pribavljanju dokaza, zaključcima iz Tamperea iznesen je nov koncept međusobne dopustivosti dokaza. Taj novi pristup pretpostavlja da bi dokazi koji su zakonito prikupljeni od vlasti jedne države članice trebali biti dopušteni na sudovima drugih država članica, uzimajući u obzir standarde koji se ondje primjenjuju. ${ }^{91}$ Međutim, ta ideja o dopustivosti dokaza bila je poželjnije razmišljanje nego realni koncept. Razlog je tomu što još postoje razlike koje proizlaze iz različitih pravnih sustava i pristupa dokazima. ${ }^{92}$ To može dovesti do situacija u kojima, s obzirom na

\footnotetext{
90 O tom pitanju raspravljali su i Kusak 2019, 392, bilj. 5; Vermeulen; De Bondt; Van Damme 2010, 254; Vermeulen 2011, 51; Armada 2015, 8-31; Bachmaier Winter 2010, 580-589; Daniele; Calvanese 2018, 354-391; Depauw 2016, 82-98; Cane; Mackarel 1996, 98-119; Cless 2006, 121-130; Heard; Mansell 2011, 353-367; Lach 2009, 107-110; Ruggeri 2014, 231; Ryan 2014, 259; Spencer 2003, 29-38.

91 European Council, Presidency Conclusions, Tampere, 15 and 16 October 1999, 36.

92 Kusak 2016, 243; Ligeti 2013, 1096.
} 
razlike između nacionalnih postupaka, dokazi prikupljeni u jednoj državi članici neće biti prihvatljivi u drugoj državi članici. Takve razlike mogu imati negativan utjecaj na uzajamno povjerenje među državama članicama, postavljati pitanja o statusu dokaza prikupljenih tijekom prekogranične suradnje i učiniti koncept međusobne dopustivosti dokaza jednostavno nerealnim. Također, postavlja se pitanje je li načelo forum regit actum u skladu s filozofijom uzajamnog priznavanja i sposobno prihvatiti pitanja prihvatljivosti u EU-u. Dobra je vijest da je Ugovor o EU-u ponudio alternativu načela forum regit actum, otvarajući mogućnost prihvaćanja minimalnih pravila koja se, između ostalog, odnose na uzajamnu prihvatljivost dokaza iz čl. 82., st. 2. Ugovora o EU-u: „Europski parlament i Vijeće mogu direktivama donesenima u skladu s redovnim zakonodavnim postupkom utvrditi minimalna pravila potrebna za olakšavanje uzajamnog priznavanja presuda i sudskih odluka te policijske i pravosudne suradnje $u$ kaznenim stvarima s prekograničnim elementima. $U$ tim se pravilima uzimaju u obzir razlike pravnih tradicija i sustava država članica. Pravila se odnose na: (a) uzajamno prihvaćanje dokaza među državama članicama...."

Zajednički minimalni standardi odgovaraju filozofiji uzajamnog priznavanja jačanjem međusobnog povjerenja među državama članicama što se tiče načina na koji se dokazi izdaju i prikupljaju. Postizanje zajedničkih minimalnih standarda zahtijevalo bi uravnoteženje potrage za prevladavanjem nacionalnih različitosti s jedne strane i prihvaćanjem činjenice međunarodne raznolikosti s druge strane. Zbog nedostatka zajedničkih minimalnih pravila prihvatljivost dokaza prikupljenih EIN-om i dalje je regulirana domaćim pravom dotičnih država članica i načelom forum regit actum. Osim toga, države članice obično nemaju ni domaća pravila o dopustivosti dokaza prikupljenih u inozemstvu (primjer je zakonodavstva koje se izravno odnosi na dopuštenost stranih dokaza koji se razlikuje od domaćih standarda Poljska i njezin čl. 587. Kodeksa). Unatoč nedostatku zajedničkih minimalnih standarda države članice zasigurno ne bi smjele isključiti dokaze prikupljene na temelju različitih pravila u odnosu na one predviđene njihovim domaćim pravom..$^{33}$

Nadalje, za razliku od prijašnjega rascjepkana i komplicirana okvira prikupljanja dokaza, EIN je sveobuhvatan i jednostavan način prikupljanja dokaza. Posebno je važno istaknuti da je zakonodavac pri propisivanju pojedinih dokaznih radnja i načina njihova provođenja ipak na određen način vodio računa o poštivanju pretpostavke okrivljenikove nevinosti te prava na obranu. Tako Zakon propisuje da će odbiti izvršenje EIN-a u slučajevima kada osumnjičenik nije suglasan s provođenjem određene dokazne radnje, npr. premještajem u RH ili iz nje osobe kojoj je oduzeta sloboda.

$S$ druge strane, Zakon propisuje razloge za odbijanje priznavanja i izvršenja EIN-a te daje velike ovlasti državi izvršiteljici pri donošenju odluke hoće li odbiti izvršiti

93 Kusak 2019, 391-400. 
EIN, što dovodi u pitanje ostvarivanje načela uzajamnog priznavanja koje je temelj pravosudne suradnje država članica u kaznenim stvarima. Zakonodavac takvu odredbu opravdava načelima učinkovite suradnje, svrhovitosti i prava na pravično suđenje, ali i sam je kontradiktoran u odredbi u kojoj govori da čim nadležno pravosudno tijelo odluči provesti dokaznu radnju koja je zatražena EIN-om, to je priznanje EIN-a i o tome se ne donosi nikakva posebna odluka. Dakle, razlozi za nepriznanje EIN-a moraju biti restriktivnije postavljeni i postojati samo u iznimnim slučajevima kako bi se omogućilo ostvarenje načela uzajamnog priznavanja te načela učinkovite suradnje.

\section{ZAKLJUČAK}

Članstvom u EU-u RH obogatila je svoju legislativu nizom novih instrumenata i mehanizama. Jedan je takav instrument EIN. Cilj je uvođenja EIN-a na razini EU-a težnja i potreba za stvaranjem slobodna, sigurna i pravedna područja unutar kojeg će države članice međusobno surađivati. Pet godina članstva u EU-u naizgled je kratak period, ali sasvim dovoljan da se možemo osvrnuti unatrag i preko dosadašnjih iskustava težiti stalnu napretku s ciljem poboljšanja uvjeta življenja na svim područjima, pa tako i u dokaznom pravu. Radom je analiziran posve nov instrument uveden $u$ hrvatsko kazneno zakonodavstvo u listopadu 2017. godine.

Analizom EIN-a uočili smo njegove prednosti i određene nedostatke. Dobre su osobine EIN-a što omogućava da se pribave ne samo postojeći dokazi nego i provedu dokazne radnje kako bi se dokazi pribavili radi vođenja kaznenog postupka u državi izdavateljici EIN-a. Zbog propisanih relativno kratkih rokova glede donošenja odluke o priznanju i izvršenju EIN-a osigurana je brža i učinkovitija suradnja između država članica. EIN je stoga nedvojbeno sveobuhvatniji instrument pribavljanja i transferiranja dokaza od onih koje smo imali prije, ali i kod njega većsada nailazimo na određena problematična pitanja koja bi mogla dovesti do poteškoća u njegovu provođenju. Jedno je takvo pitanje pitanje razloga za nepriznavanje ili neizvršenje EIN-a. Analizom smo uočili da i Direktiva i Zakon, što se tiče razloga za nepriznavanje ili neizvršenje EIN-a, sadržavaju kontradiktorne odredbe, propisujući da nadležno tijelo države izvršiteljice priznaje EIN bez zahtjeva za dodatnim formalnostima, a zatim navodi da nadležno tijelo države izvršiteljice može napraviti drugu mjeru od one koja je zatražena EIN-om pod određenim uvjetima. Osim toga, razlozi za nepriznavanje i neizvršenje EIN-a mnogo su širi od onih koje imamo u čl. 42.j Zakona.

Drugo, osobito je važno pitanje pitanje očuvanja temeljnih ljudskih prava pri izdavanju i izvršenju EIN-a. Ovdje je uočeno kršenje načela jednakosti oružja obrane i državnog odvjetnika zbog nemogućnosti obrane da pribavlja dokaze u istražnom postupku barem u situacijama kad se EIN izdaje na zahtjev osumnjičenika, odnosno 
njegova odvjetnika. Osim toga, u tom slučaju za obranu nisu osigurani pravni lijekovi protiv rješenja kojim sud odbije priznati i izvršiti EIN. Kod troškova uočili smo da Direktiva i Zakon ne sadržavaju odredbe o izvršenju EIN-a u slučaju kad se države ne mogu dogovoriti oko troškova izvršenja EIN-a, a takvo je pitanje od iznimna značenja za samo provođenje dokaznih radnja. Rekli bismo da je najveća prepreka u ostvarivanju učinkovite suradnje država članica glede tog instrumenta dopustivost i zakonitost dokaza pribavljenih u državama članicama s različitim nacionalnim zakonodavstvima. Posljedica tih poteškoća nalazi se u načelu forum regit actum na kojem počiva EIN jer dovodi u pitanje prihvatljivost dokaza u državi izdavateljici EIN-a. To pitanje moglo bi se riješiti prihvaćanjem minimalnih pravila na kojima bi počivalo načelo uzajamnog priznavanja, tako da bi različiti pravni sustavi posežući za njima mogli brže i lakše transferirati dokaze i omogućiti njihovu uporabu u kaznenim postupcima drugih država članica.

\section{LITERATURA}

Armada, I. (2015). The European investigation order and the lack of European standards for gathering evidence: Is a fundamental rights-based refusal the solution? New Journal of European Criminal Law, 6 (1), 8-31. https://doi.org/10.1177/203228441500600103

Allegrezza, S. (2010). Critical remarks on the Green Paper on Obtaining Evidence in Criminal Matters from one Member State to another and Securing its Admissibility. ZIS: Zeitschrift für Internationale Strafrechtsdogmatik, 5 (9), 569-579. Dostupno na http://zis-online.com/ dat/artikel/2010_9_489.pdf.

Bachmaier Winter, L. (2010). European Investigation Order for obtaining evidence in the criminal proceedings. Study of the proposal for European Directive. ZIS: Zeitschrift für Internationale Strafrechtsdogmatik, 5 (9), 580-589. Dostupno na http://www.zis-online.com/dat/ artikel/2010_9_490.pdf.

Burić, Z.; Hržina, D. (2014). Pribavljanje i osiguranje dokaza te osiguranje i oduzimanje imovine i predmeta prema Zakonu o pravosudnoj suradnji u kaznenim stvarima s državama članicama Europske unije. Hrvatski ljetopis za kazneno pravo i praksu, 21 (2), 355-400. Dostupno na https://hrcak.srce.hr/143586

Crnčec, I.; Mišerda, T. (2017). Novela Zakona o pravosudnoj suradnji u kaznenim stvarima s državama članicama Europske unije. Hrvatski ljetopis za kaznene znanosti i praksu, 24 (2),525-551. Dostupno na https://hrcak.srce.hr/file/289403.

Daniele, M.; Calvanese, E. (2018). Evidence gathering. In: Kostoris, R. E. (ed.). Handbook of European Criminal Procedure. Springer. Berlin. 353-391.

https://doi.org/10.1007/978-3-319-72462-1_9

Depauw, S. (2016). A European evidence (air)space? Taking cross border legal admissibility of forensic evidence to a higher level. EuCLR: European Criminal Law Review, 6 (1), 82-98. https://doi.org/10.5771/2193-5505-2016-1-82 
Đurđević, Z. (2009). Procesna jamstva obrane prema suokrivljeniku kao svjedoku optužbe. Hrvatski ljetopis za kazneno pravo i praksu, 16 (2), 783-808. Dostupno na https://hrcak.srce. $\mathrm{hr} / 89508$

Gane, C.; Mackarel, M. (1996). The admissibility of evidence obtained from abroad into criminal proceedings - the interpretation of mutual legal assistance treaties and use of evidence irregularly obtained. European Journal of Crime, Criminal Law and Criminal Justice, 4(2), 98-119.

Gless, S. (2006). Free movement of evidence in Europe. In: Deu, T. A.; Inchausti, F. G.; Hernen, M. C. (eds.). El Derecho procesal penal en la Unión Europea: tendencias actuales y perspectivas de futuro. Madrid. 121-130.

Heard, C.; Mansell, D. (2011). The European Investigation Order: Changing the face of evidence-gathering in EU cross - border cases. New Journal of European Criminal Law, 2(4), 353-367. https://doi.org/10.1177/203228441100200402

Hržina, D. (2018). Novela Zakona o pravosudnoj suradnji u kaznenim stvarima s državama članicama Europske unije: priručnik za polaznike/ice. Pravosudna akademija. Dostupno na http://pak.hr/cke/obrazovni\%2omaterijali/Priručnik\%20za\%2opolaznike\%20Novela\%20 ZPSKS-EU.pdf

Jurka, R.; Zajančkauskienè, J. (2016). Movement of Evidence in the European Union: Challenges for the European Investigation Order. Baltic Journal of Law, 9 (2), 56-84. Dostupno na doi: https://doi.org/10.1515/bjlp-2016-0012

Klimek, L. (2012). Free Movement of Evidence in Criminal Matters in the EU. The Lawyer Quarterly 2 (4) 250-290. Dostupno na: https://tlq.ilaw.cas.cz/index.php/tlq/article/download/49/40

Kusak, M. (2016). Mutual Admissibility of Evidence in Criminal Matters in the EU. A Study of Telephone Tapping and House Search. Maklu. Antwerpen - Apeldoorn - Portland.

Kusak, M. (2019). Mutual admissibility of evidence and the European investigation order: aspirations lost in reality. ERA Forum, 19 (3), 391-400.

https://doi.org/10.1007/s12027-018-0537-0

Lach, A. (2009). Transnational Gathering of Evidence in Criminal Cases in the EU de lege lata and de lege ferenda, Eucrim, 3, 107-110. Dostupno na https://eucrim.eu/media/issue/pdf/eucrim_issue_2009-03.pdf

Ligeti, K. (ed.). (2013). Toward a Prosecutor for the European Union. Vol. 1: A Comparative Analysis. Hart Publishing. Oxford and Portland. Oregon.

Mangiaracina, A. (2014). A new and controversial scenario in the gathering of evidence at the European level: The proposal for a Directive on the European Investigation Order. Utrecht Law Review, 10 (1), 113-133.

https://doi.org/10.18352/ulr.260

Mitsilegas, V. (2009). The third wave of third pillar law: which direction for EU criminal justice? European Law Review, 34 (4), 523-559. Dostupno na https://papers.ssrn.com/sol3/papers.cfm?abstract_id=1487664

Navickaitè, S. (2016). The European Investigation Order: achievements and challenges. Social Transformations in Contemporary Society, (4), 109-120. Dostupno na http://stics.mruni.eu/ wp-content/uploads/2016/07/STICS_2016_4_109-120.pdf. 
Peers, S. (2010). The proposed European Investigation Order: Assault on human rights and national sovereignty. Statewatch. Dostupno na http://www.statewatch.org/analyses/ no-96-european-investigation-order.pdf

Petrić, S. (2009). Zajednički istražni timovi u Europskoj uniji. Policijska sigurnost, 18 (4), 532538. Dostupno na: https://hrcak.srce.hr/file/117964.

Primorac, D. (2018). Europski uhidbeni nalog: teorija i praksa. Scientiae et Artes. Zagreb.

Ruggeri, S. (ed.). (2014). Transnational Evidence and Multicultural Inquiries in Europe. Springer. Berlin.

https://doi.org/10.1007/978-3-319-02570-4

Ryan, A. (2014). Towards a System of European Criminal Justice. The Problem of Admissibility of Evidence. Routledge. London.

https://doi.org/10.4324/9781315770031

Sayers, D. (2011). The European Investigation Order Travelling without a 'roadmap'. CEPS Liberty and Security in Europe. June. Dostupno na https://www.ceps.eu/system/files/ book/2011/06/No\%2042\%20Sayers\%200n\%20European\%2olnvestigation\%20Order. pdf.

Spencer, J. R. (2003). The concept of 'European Evidence'. ERA Forum, 4 (2), 29-38. https://doi.org/10.1007/s12027-003-0005-2

Staes, D. (2011). The Interrogation of Witnesses abroad in Execution of a European Investigation Order. An Examination from the Eyes of the Defence. Master Thesis. Universidade Nova de Lisboa. Dostupno na http://run.unl.pt/bitstream/10362/6214/1/Staes_2011.PDF.

Vermeulen, G.; De Bondt, W.; Van Damme, Y. (2010). EU Cross Border Gathering and Use of Evidence in Criminal Matters. Towards Mutual Recognition of Investigative Measures and Free Movement of Evidence? Maklu. Antwerpen - Apeldoorn - Portland.

Vermeulen, G. (2011). Free gathering and movement of evidence in criminal matters in the EU: thinking beyond borders, striving for balance, in search of coherence. Maklu. Antwerpen - Apeldoorn - Portland.

Vogel, J.; Spencer, J.R. (2010). Proportionality and the European Arrest Warrant, Criminal Law Review (6), 474-482.

Vržina, K. (2015). Zaštita postupovnih prava obrane. Hrvatski ljetopis za kazneno pravo i praksu, 22 (1), 217-242.

Vuletić, I. (2016). Pravo EU u kaznenom i kaznenom procesnom pravu. u: Ljubanović, B.; Petrašević, T.; Poretti, P.; Vuletić, I.; Župan, M. Procesno pravni aspekti prava EU. Pravni fakultet Sveučilišta Josipa Jurja Strossmayera u Osijeku. Osijek. 66-90.

Zaharieva, R. (2017). The European Investigation Order and the Joint Investigation Team which road to take, ERA Forum, 18 (3), 397-408

https://doi.org/10.1007/s12027-017-0483-2 
Council Framework Decision 2002/465/JHA of 13 June 2002 on joint investigation teams, Službeni list Europske unije O] L 162, 20. 6. 2002. Dostupno na https://www.europol.europa. eu/activities-services/joint-investigation-teams.

Council Framework Decision 2003/577/JHA of 22 July 2003 on the execution in the European Union of orders freezing property or evidence, Službeni list Europske unije O] L 196, 2. 8. 2003. Dostupno na https://eur-lex.europa.eu/legal-content/HR/TXT/?uri=celex\%3A32003Fo577.

Council Framework Decision 2008/978/JHA of 18 December 2008 on the European evidence warrant for the purpose of obtaining objects, documents and data for use in proceedings in criminal matters. Dostupno na https://eur-lex.europa.eu/legal-content/HR/TXT/?uri=CELEX:32008Fo978.

Directive 2014/41/EU of the European Parliament and of the Council of 3 April 2014 regarding the European Investigation Order in criminal matters, Službeni list Europske unije O] L 130, 1. 5. 2014. Dostupno na https://eur-lex.europa.eu/legal-content/HR/TXT/?uri=celex\%3A32014L0041.

European Council, Presidency Conclusions, Tampere, 15 and 16 October 1999.

Europska konvencija za zaštitu ljudskih prava i temeljnih sloboda, NN-MU, br. 18/97, 14/02, 13/03, 9/05, 1/06, 2/10.

European Investigation Order - APP - Guidance. Dostupno na http://library.college.police. uk/docs/appref/The-European-Investigation-Order-APP-Guidance-Final.docx.

Europska konvencija Vijeća Europe o uzajamnoj pravnoj pomoći u kaznenim stvarima od 20. travnja 1959. godine, kao i njezina dva dodatna protokola, te bilateralni sporazumi sklopljeni na temelju čl. 26. navedene Konvencije, NN, br. 4/99.

JUSTICE. 2012. European Arrest Warrant. Ensuring an Effective Defence. Dostupno na http:// www.ecba.org/extdocserv/projects/EAW/JUSTICE_EAW.pdf.

Konvencija o provedbi Schengenskog sporazuma od 14. lipnja 1985. između vlada država Cospodarske unije Beneluksa, Savezne Republike Njemačke i Francuske Republike o postupnom ukidanju kontrola na zajedničkim granicama, Službeni list Europske unije O] L. 239/19. Dostupno na https://eur-lex.europa.eu/legal-content/HR/TXT/?uri=celex\%3A42000A0922\%2802\%29.

Okvirna odluka Vijeća Europske unije od 13. lipnja 2002. o zajedničkim istražiteljskim ekipama (2002/456/PUP), (SL L 162, 20. 6. 2002.).

Prekršajni zakon, NN, br. 107/07, 39/13,157/13,110/15 i 70/17.

The Stockholm Programme - An open secure Europe serving and protecting citizens, 17024/09, Bruxelles, 2009. Dostupno na http://eurlex.europa.eu/legal-content/LT/TXT/PDF/?uri=CELEX:52010XC0504(01)\&from=EN.

Uredba (EU) 2016/95 Europskog parlamenta i Vijeća od 20. siječnja 2016. godine o stavljanju izvan snage određenih akata u području policijske i pravosudne suradnje u kaznenim stvarima, (SL L 26, 2. 2. 2016.) 


\section{Summary}

\section{EUROPEAN INVESTICATION ORDER AS A NEW INSTRUMENT OF JUDICIAL COOPERATION BETWEEN MEMBER STATES IN CRIMINAL CASES WITH A SPECIAL FOCUS ON CROATIAN LAW}

The accession of the Republic of Croatia to the European Union opened a whole new era in its historical and social development. In the area of criminal law, this involves the implementation and harmonization of a number of institutes aimed at facilitating the treatment of judicial organs and their cooperation in criminal cases between Member States. Over a period of five years, certain steps have been taken in this direction. However, in addition to analyzing the results achieved in this period, it is very important to point to open questions whose practical implications will be discussed. Therefore, the aim of this paper is to point to the institute of European Investigation Order, which was introduced in Croatian criminal legislation by the Act on Amendments of the Law on Judicial Co-operation in Criminal Matters with the Member States of the European Union of October 2017 in accordance with Directive 2014/41 / EU of the European Parliament and of the Council of April 3th 2014 on a European Investigation Order in Criminal Matters, which is a new institute in the legal systems of other Member States. Following the implementation of the European Arrest Warrant, the European Investigation Order is a continuation of the efforts to harmonize activities of judicial organs of EU Member States in criminal proceedings with the aim of obtaining evidence through investigative measures. Although its implications will be seen in the future, the paper discusses all the advantages of its introduction and the deficiencies that arise from the interpretation of certain legal provisions by criminal law scholars.

Key words: European Investigation Order; judicial co-operation; conducting special investigative measures; the issuing state; executing state 